\title{
Root growth and turnover in perennial forages as affected by management systems and soil depth
}

\author{
Stéphanie Houde • Marie-Noëlle Thivierge • \\ Florian Fort • Gilles Bélanger • Martin H. Chantigny • \\ Denis A. Angers • Anne Vanasse
}

Received: 14 December 2019 / Accepted: 8 April 2020 /Published online: 27 April 2020

(C) The Author(s) 2020

\begin{abstract}
Aims Extensive knowledge of perennial forage root systems is essential, given their critical role in belowground $\mathrm{C}$ input.

Methods Root length and diameter were quantified periodically from 2016 to 2018 with minirhizotrons in a field experiment with three forage management systems: mixture of timothy (Phleum pratense L.) and tall fescue (Festuca arundinacea Schreb.) fertilized with (i) dairy cattle slurry or (ii) calcic ammonium nitrate, and (iii) mixture of timothy, tall fescue, and alfalfa (Medicago sativa L.) without $\mathrm{N}$ fertilization. Root biomass was measured yearly by coring.

Results Management systems with the two fertilization sources did not differ in root elongation, but the management system with alfalfa resulted in a slower root elongation after the first defoliation and a lower root mortality in the fall. Root length turnover was greater in
\end{abstract}

Responsible Editor: Peter Christie.

S. Houde $\cdot$ A. Vanasse

Department of Phytology, Université Laval, Quebec City, QC

G1V 0A6, Canada

S. Houde $\cdot$ M.-N. Thivierge $(\bowtie) \cdot$ G. Bélanger $\cdot$

M. H. Chantigny · D. A. Angers

Quebec Research and Development Centre, Agriculture and

Agri-Food Canada, Quebec City, QC G1V 2J3, Canada

e-mail: Marie-Noelle.Thivierge@ canada.ca

F. Fort

CEFE, Univ Montpellier, CNRS, EPHE, Institut Agro, IRD,

Montpellier SupAgro, 34293 Montpellier, France the topsoil with dairy cattle slurry than with calcic ammonium nitrate. Fine roots dominated the surface soil and coarse roots the deeper soil layers.

Conclusions Root growth and mortality were more contrasted between systems that differed by the presence of alfalfa than by fertilizer source. As many root characteristics are drivers of soil C storage, the choice of perennial species in mixtures appears as a key management factor for sustainable farming systems.

Keywords Root length - Root diameter - Root turnover Forage mixture $\cdot$ Dairy cattle slurry $\cdot$ Minirhizotron

\section{Abbreviations \\ DM Dry matter}

\section{Introduction}

Root-related ecosystem services provided by perennial forage crops are fundamental to the sustainability of modern farming, especially for livestock-based systems (Gregory et al. 2013; Ojeda et al. 2017; Soussana et al. 2014). In particular, well-managed grasslands and perennial-based cropping systems can maintain and accumulate soil $\mathrm{C}$ and hence contribute to climate change mitigation (Poeplau et al. 2018). The trait-based approach is usually favoured by plant ecologists to assess functions, changes, and shifts in plant tissues in response to environmental gradients in ecosystems and to estimate the effect of these changes on ecosystem 
functioning. This approach is also well-suited for agroecosystems in order to understand how management practices influence ecosystem processes such as soil C storage and nutrient cycling (Bardgett et al. 2014; De Deyn et al. 2008; Martin and Isaac 2015), and thus promote sustainable agricultural intensification (Faucon et al. 2017).

Research on root systems and the resulting $\mathrm{C}$ inputs from perennial crops are usually based on measurements of total root mass at a given time (Bolinder et al. 2012). However, total root biomass might not be the best predictor of root-derived $\mathrm{C}$, since it combines all types of roots, regardless of their functions. Indeed, root biomass combines two "functional compartments", namely the acquisitive fine, short-lived, and absorptive roots, and the conservative thick roots and rhizomes dedicated to water transport and resource storage (Klimesova et al. 2018). These two types of roots could contribute in different ways to below-ground $\mathrm{C}$ input (Freschet et al. 2017; Poirier et al. 2018). Moreover, root turnover is proposed as the main driver of C storage potential (Goss and Watson 2003). Turnover, i.e. root growth and mortality fluxes, is likely to be more significant in perennial crops than in annual crops. Recent studies have set the groundwork of trait-based approaches for herbaceous perennials. Legumes and grass-legume mixtures were overlooked, while they are thought to induce different rooting patterns than grasses (Hernandez and PiconCochard 2016).

High nutrient availability in shallow soil layers tends to trigger intense soil exploration by fine roots, resulting in high specific root length and root length density (Mommer et al. 2011; Prieto et al. 2015). In addition, roots developing in nutrient-rich soils are expected to be short-lived and characterized by a high $\mathrm{N}$ concentration (Kramer-Walter and Laughlin 2017; McCormack and Guo 2014). Roots in deeper soil layers have lower tissue density and are generally coarser (Fort et al. 2016, 2017) and longer-lived (Wu et al. 2013). Rooting depth was recently identified as a key driver of soil organic matter stabilization, as deep roots are better protected from decay due to their proximity to mineral particles and their inclusion within stable soil aggregates (Rasse et al. 2005; Poirier et al. 2018).

Root traits exhibit strong seasonal patterns (Chen et al. 2016), which are likely to be modulated by soil depth and management practices (Fan et al. 2016; Lazicki et al. 2016) and, hence, to influence rootderived soil C fluxes (Poirier et al. 2018). Defoliation in perennial grass pasture species was shown to increase root turnover, while also inducing a smaller root system (McInenly et al. 2010; Reid et al. 2015). Ensuing defoliation and under high $\mathrm{N}$ conditions, root architecture of grasses showed a reduced average root diameter (Dawson et al. 2004).

Nitrogen amendment is known to enhance belowground productivity, while also increasing soil organic $\mathrm{C}$ stock through greater use efficiency of $\mathrm{C}$ inputs for microbial growth (Ghafoor et al. 2017; Poeplau et al. 2018). Whether an organic or an inorganic source of $N$ is used might modify soil conditions. Over the longterm, organic amendments have been shown to enhance soil organic $\mathrm{C}$ and $\mathrm{P}$ contents, and microbial biomass (Chen et al. 2018). Thus, as soil conditions differ under organic vs. inorganic N, root lifespan and responses for productivity also are presumably dissimilar, especially near the soil surface (Baldi et al. 2010; Fort et al. 2016), but evidence for this is scarce. Ultimately, based on symbiotic $\mathrm{N}$ fixation by legumes and on the mutual stimulatory effects on $\mathrm{N}$ acquisition by grasses and legumes (Nyfeler et al. 2011), growing grass-legume mixtures is an advocated cropping strategy to decrease synthetic $\mathrm{N}$ fertilizer dependency and improve soil quality and C storage (Jensen et al. 2012; Lüscher et al. 2014).

Refining our knowledge of the seasonal rooting pattern of perennial forage crops at different soil depths and over multiple growing seasons could reduce uncertainties related to the influence of management practices at the plant community level. Through an in situ, nondestructive trait-based approach, we aimed (i) to monitor and quantify root growth dynamics and root length turnover of different perennial forage mixtures through successive defoliations and growing seasons and (ii) to test whether spatial and temporal root deployment were responsive to distinct forage management systems varying in plant species composition and $\mathrm{N}$ source.

\section{Materials and methods}

Site description

This study was conducted at the Laval University Agronomic Research Station in Saint-Augustin-deDesmaures (Quebec, Canada, Lat. $46^{\circ} 43^{\prime} \mathrm{N}$; Long. $71^{\circ} 30^{\prime} \mathrm{W}$ ) from 2016 to 2018 . The soil, a Tilly silty clay (fine, mixed, non-acid, frigid Aquic Haplorthod), 


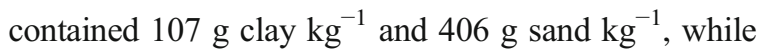
pH was $6.7(0-15 \mathrm{~cm})$. Soil organic $\mathrm{C}$ and total $\mathrm{N}$ concentrations (dry combustion) were 22.1 and $2.6 \mathrm{~g} \mathrm{~kg}^{-1}$, respectively, and the cation exchange capacity was 18.2 mol $_{\mathrm{c}} \mathrm{kg}^{-1}$. Mehlich-3 available $\mathrm{P}$ and $\mathrm{K}$ were respectively 39 and $487 \mathrm{~kg} \mathrm{ha}^{-1}$. Long-term mean annual air temperature and precipitation (1981-2010) were $4.2{ }^{\circ} \mathrm{C}$ and $1190 \mathrm{~mm}$, respectively (Environment Canada 2018).

Experimental set-up and crop management

Species sown in the study included timothy (Phleum pratense L. 'AC Alliance', Sollio Groupe Coopératif, QC, CA), tall fescue (Festuca arundinacea Schreb. 'Carnival', DLF Pickseed Canada, ON, CA), and alfalfa (Medicago sativa L. 'Calypso', Sollio Groupe Coopératif, QC, CA). These selected cultivars are widely used and recommended in eastern Canada (CRAAQ 2016).

The experimental treatments consisted of three forage management systems commonly used in eastern Canadian dairy farms: (i) SLU: a mixture of timothy and tall fescue fertilized with dairy cattle slurry, (ii) CAN: a mixture of timothy and tall fescue fertilized with calcic ammonium nitrate, and (iii) ALF: a mixture of timothy, tall fescue, and alfalfa unfertilized during post-seeding years. In the grass-only mixtures (SLU and CAN), timothy and tall fescue were seeded at rates of 7 and $10 \mathrm{~kg} \mathrm{ha}^{-1}$, respectively. For the grass-alfalfa mixture (ALF), seeding rates were 6,8 , and $9 \mathrm{~kg} \mathrm{ha}^{-1}$ for timothy, tall fescue, and alfalfa, respectively. The forage species were broadcast seeded on 12 May 2016 in a randomized complete block design with three replications, and were immediately underseeded with barley (Hordeum vulgare L. 'Oceanik', Synagri, QC, CA, $123 \mathrm{~kg}$ seeds $\mathrm{ha}^{-1}, 18 \mathrm{~cm}$ between rows). Plot size was $6.0 \mathrm{~m} \times 10.0 \mathrm{~m}$.

To ensure good forage establishment and barley growth, all plots were fertilized in 2016 with $100 \mathrm{~kg}$ available $\mathrm{N} \mathrm{ha}^{-1}$, either with calcic ammonium nitrate (for CAN and ALF) or dairy cattle slurry (for SLU). Information about $\mathrm{N}$ application rates and timing is summarized in Table 1. For the post-seeding years (2017 and 2018), the ALF treatment did not receive any $\mathrm{N}$ fertilization, while the SLU and CAN treatments received $150 \mathrm{~kg}$ available $\mathrm{N} \mathrm{ha}^{-1}$ as a split application (Table 1). Available $\mathrm{N}$ in the slurry was estimated to be $70 \%$ of total $\mathrm{N}$ in mineral and organic forms (CRAAQ
2010). Selected characteristics of the slurry are presented in Table 2. The $\mathrm{P}$ and $\mathrm{K}$ requirements of the CAN and ALF management systems were met as per local recommendation (CRAAQ 2010).

Forages were harvested once in 2016 (2 Sept.) and three times in 2017 and 2018, at a 7-cm height with a self-propelled flail forage harvester (Carter Mfg. Co., Brookston, IN). Forages were harvested when tall fescue reached the late boot/early heading stage at the first cut (6 June 2017 and 2018), and with an interval of approximately 35 days between the following cuts. No cuts were taken in the fall to favor winter survival.

\section{Root measurements}

\section{Minirhizotron system}

Before seeding forage crops in spring 2016, three minirhizotrons consisting of transparent cellulose acetate butyrate tubes with a 5.1-cm interior diameter and a $120-\mathrm{cm}$ length were installed in each plot $(9$ plots $\times 3$ tubes $=27$ tubes $)$. They were inserted into the soil at an angle of $30^{\circ}$ to the vertical and to a vertical depth of $60 \mathrm{~cm}$. The tubes were sealed at the lower end, and protected from rain and sunlight entry by an opaque white plastic cap at the upper end.

Minirhizotrons allowed for continuous nondestructive root observation, except during the winter periods when the field was snow-covered from December to April. Root images were taken once in 2016 on 4 Oct. In 2017, images were collected weekly from 4 May to 6 Sept., and every 2 weeks from 21 Sept. to 30 Nov., for a total of 24 photo sessions. In 2018, images were collected weekly from 25 Apr. to 6 June (first defoliation), and then on 12 July (second defoliation) and on 18 Oct. (fall), for a total of seven photo sessions. Images were collected using a video camera (Model BTC100X, Bartz Technology Corporation, CA, USA) attached on the upper end of the tubes. The attachment system allowed the camera to slide down the tube from a reference point, thus ensuring the same soil depths at each photo session. Images $(1.35 \mathrm{~cm}$ high by $1.80 \mathrm{~cm}$ wide, magnified 15.0X) were taken every $1.35 \mathrm{~cm}$ down to a $60-\mathrm{cm}$ depth, resulting in a complete image of the soil profile in each tube. Thus, approx. 1500 images were taken in every photo session, resulting in 36,000 images in 2017 and 10,500 in 2018. 
Table 1 Nitrogen fertilization summary for the three forage management systems (SLU, a mixture of timothy and tall fescue fertilized with dairy cattle slurry; CAN, a mixture of timothy and tall fescue fertilized with calcic ammonium nitrate and; ALF, a mixture of timothy, tall fescue, and alfalfa unfertilized during postseeding years) in 2016, 2017, and 2018

\begin{tabular}{|c|c|c|c|c|c|}
\hline & & & $\begin{array}{l}\mathrm{SLU}^{\mathrm{a}} \\
\mathrm{kg} \text { available } \mathrm{N} \mathrm{ha}^{-1}\end{array}$ & $\mathrm{CAN}^{\mathrm{b}}$ & $\mathrm{ALF}^{\mathrm{b}}$ \\
\hline \multirow[t]{2}{*}{2016} & Spring $^{\mathrm{c}}$ & 11-12 May & 67 & 60 & 60 \\
\hline & 1st defoliation $\mathrm{d} /$ fall & 2 Sept. & 40 & 40 & 40 \\
\hline \multirow[t]{2}{*}{2017} & Spring & 16 May & 89 & 90 & 0 \\
\hline & 1st defoliation & 12 June & 66 & 60 & 0 \\
\hline \multirow[t]{2}{*}{2018} & Spring & 10 May & 94 & 90 & 0 \\
\hline & 1st defoliation & 11 June & 60 & 60 & 0 \\
\hline
\end{tabular}

${ }^{a}$ Available $\mathrm{N}$ from dairy cattle slurry (Table 2) was considered to be $70 \%$ of total N (CRAAQ 2010);

${ }^{\mathrm{b}}$ Applied as calcic ammonium nitrate;

${ }^{\mathrm{c}}$ Incorporated by harrowing before seeding;

${ }^{\mathrm{d}} \mathrm{N}$ fertilizers were applied 5 to 6 days following the first defoliation every year

\section{Image analysis}

Images were analyzed using the WinRhizoTRON MF 2018a (Regent Instruments, QC, CA) software. The soil profile was divided into four layers from the soil surface: $0-15,15-30,30-45$, and 45-60 cm. For all images, all roots were hand traced using a 2.0X magnification level. Length and diameter were directly measured for live roots. Over such a long project (3 years), four research assistants were involved in root tracing. To minimize the operator effect (Ingram and Leers 2001), the same person trained all operators and supervised them in their work. Moreover, the hand-traced images were randomly validated visually and appropriate corrections were made when necessary.

\section{Calculations}

Daily elongation of live roots was computed by performing piecewise linear regressions (SAS 9.4 2013), using root length as a function of the number of days between sampling dates of pre-determined periods. Spring periods started with the first N amendment and stopped at the first defoliation; subsequent postdefoliation periods were the 5 weeks ensuing a defoliation, while the fall period covered the rest of the growing season until 30 Nov. in 2017. Photo sessions prior to the first $\mathrm{N}$ fertilization are referred to as early spring (4 May to 12 May 2017, and 25 Apr. to 7 May 2018). Precise dates and the number of photo sessions used for the

Table 2 Selected characteristics of dairy cattle slurry in 2016, 2017, and 2018

\begin{tabular}{|c|c|c|c|c|c|c|c|c|c|}
\hline \multicolumn{3}{|c|}{ Application } & \multirow[t]{2}{*}{$\mathrm{pH}$} & \multirow{2}{*}{$\begin{array}{l}\mathrm{DM}^{\mathrm{a}} \\
\mathrm{g} \mathrm{L}^{-1}\end{array}$} & \multirow[t]{2}{*}{$\mathrm{C}: \mathrm{N}^{\mathrm{b}}$} & \multirow{2}{*}{$\begin{array}{l}\text { Total } \mathrm{N}^{\mathrm{c}} \\
\mathrm{g} \mathrm{kg}^{-1} \mathrm{DM}\end{array}$} & \multirow[t]{2}{*}{$\mathrm{NH}_{4}-\mathrm{N}^{\mathrm{d}}$} & \multirow[t]{2}{*}{$\mathrm{NO}_{3}-\mathrm{N}^{\mathrm{d}}$} & \multirow[t]{2}{*}{$\mathrm{P}$} \\
\hline Year & Timing & $\begin{array}{l}\text { Rate } \\
\mathrm{L} \mathrm{m}^{-2}\end{array}$ & & & & & & & \\
\hline \multirow[t]{2}{*}{2016} & Spring & 4.0 & 6.8 & 59.5 & 10.4 & 4.0 & 2.1 & 0.06 & 0.8 \\
\hline & 1st defoliation & 2.5 & 7.3 & 70.1 & 12.5 & 3.3 & 1.3 & 0.03 & 0.7 \\
\hline \multirow[t]{2}{*}{2017} & Spring & 5.0 & 7.1 & 66.3 & 10.9 & 3.8 & 1.6 & 0.05 & 0.7 \\
\hline & 1st defoliation & 3.5 & 8.4 & 68.2 & 10.6 & 3.9 & 1.7 & 0.05 & 0.8 \\
\hline \multirow[t]{2}{*}{2018} & Spring & 5.8 & 7.0 & 43.9 & 14.0 & 5.3 & 2.7 & 0.03 & 0.3 \\
\hline & 1st defoliation & 3.8 & 7.3 & 40.8 & 14.6 & 5.6 & 3.0 & 0.05 & 0.3 \\
\hline
\end{tabular}

\footnotetext{
${ }^{\mathrm{a}} \mathrm{DM}$, dry matter;

${ }^{\mathrm{b}} \mathrm{C}: \mathrm{N}$, carbon-to-nitrogen ratio;

${ }^{\mathrm{c}}$ Determined by acid digestion;

${ }^{\mathrm{d}}$ Determined by $\mathrm{KCl}$ extraction
} 
calculation of root elongation rates are presented in Table 3A.

Total root length was distributed into 10 diameter classes with 100- $\mu$ m increments. Root length in each class was then expressed as a proportion of total root length. This variable is referred to as root length distribution (Table 3B).

Root mortality, assessed by the decline in root length, was estimated in 2017 as the difference between the maximum live root length observed at end of summer (see Table 3C for exact dates) and minimum values observed either in early fall when root biomass was also assessed by soil coring, or in late fall with the last photo session. Root mortality was calculated for each tube and averaged for each treatment. Root length turnover was calculated as the root mortality divided by the minimum live root length observed in either early or late fall. Details about these periods are provided in Table $3 \mathrm{C}$. Overwinter changes in root length and diameter were calculated for the 2016-2017 winter and for the 2017-
2018 winter with either the early or late fall measurements in 2017 (Table 3D). Finally, a distribution of root length over four soil layers of the soil profile was calculated (Table 3E).

\section{Root biomass}

Root biomass was assessed by soil coring to a 45-cm depth in the falls of 2016, 2017, and 2018 (Table 3E). Three 7.5$\mathrm{cm}$ soil cores per plot were taken and divided into three soil layers: 0-15, 15-30, and 30-45 cm. Roots were separated from the soil with a hydropneumatic elutriation system (Smucker et al. 1982) using a 760- $\mu$ m primary sieve and a $290-\mu \mathrm{m}$ secondary sieve following a 16-h pre-soaking in a sodium hexametaphosphate solution $\left(100 \mathrm{~g} \mathrm{~L}^{-1}\right)$. Separated roots were dried at $55{ }^{\circ} \mathrm{C}$ until constant weight and analyzed for total $\mathrm{N}$ and $\mathrm{C}$ concentration by dry combustion (LECO CNS-1000, Leco Corp., St. Joseph, MI). Ash content was determined by heating root subsamples to $600{ }^{\circ} \mathrm{C}$ until a constant weight using a thermogravimetric

Table 3 Periods and dates of measurements, and number of photo sessions used in five root analyses (A to E)

\begin{tabular}{|c|c|c|c|c|c|}
\hline & Analysis & Year & Period & Dates & Number of photo sessions \\
\hline \multirow[t]{6}{*}{ A } & \multirow[t]{6}{*}{ Root elongation rates } & 2017 & Spring & 16 May to 6 June & 3 \\
\hline & & 2017 & Post-defoliation 1 & 7 June to 12 July & 5 \\
\hline & & 2017 & Post-defoliation 2 & 18 July to 16 Aug. & 5 \\
\hline & & 2017 & Post-defoliation 3 & 24 Aug. to 5 Oct. & 5 \\
\hline & & 2017 & Fall & 18 Oct. to 30 Nov. & 4 \\
\hline & & 2018 & Spring & 10 May to 6 June & 3 \\
\hline B & $\begin{array}{l}\text { Root length distribution by } \\
\text { diameter classes }\end{array}$ & 2017 & & All & 24 \\
\hline \multirow[t]{2}{*}{$\mathrm{C}$} & \multirow[t]{2}{*}{ Root mortality and turnover } & 2017 & End of summer to early fall & $\begin{array}{c}\text { [25 July - } 6 \text { Sept.] to } \\
\text { [5 Oct. - } 1 \text { Nov. }]\end{array}$ & 7 and 3 \\
\hline & & 2017 & End of summer to late fall & $\begin{array}{l}\text { [25 July - } 6 \text { Sept.] to } \\
\text { [15 Nov. - } 30 \text { Nov.] }\end{array}$ & 7 and 2 \\
\hline \multirow[t]{3}{*}{$\mathrm{D}$} & \multirow{3}{*}{$\begin{array}{l}\text { Overwinter changes in root } \\
\text { length and diameter }\end{array}$} & 2016 to 2017 & & 4 Oct. and 4 May & 2 \\
\hline & & 2017 to 2018 & Late fall to early spring & 30 Nov. and 25 Apr. & 2 \\
\hline & & 2017 to 2018 & Early fall to early spring & 18 Oct. and 25 Apr. & 2 \\
\hline \multirow[t]{3}{*}{$\mathrm{E}$} & \multirow{3}{*}{$\begin{array}{l}\text { Fall root length and biomass } \\
\text { distribution over soil depth }\end{array}$} & 2016 & Early fall & 4 Oct. $^{\mathrm{a}}, 5$ Oct. & 1 \\
\hline & & 2017 & Early fall & 5 Oct. $^{\mathrm{a}}, 19$ Oct. $^{\mathrm{b}}$ & 1 \\
\hline & & 2018 & Early fall & 18 Oct. ${ }^{\mathrm{a}}, 12$ Oct. $^{\mathrm{b}}$ & 1 \\
\hline
\end{tabular}

${ }^{\mathrm{a}}$ Date of root length measurement;

${ }^{\mathrm{b}}$ Date of root biomass measurement 
analyzer (TGA701, Leco Corp., St. Joseph, MI), and ashfree biomass was calculated (Bolinder et al. 2002).

Plant aboveground measurements and analyses

Forage dry matter (DM) yield was measured on each defoliation by cutting an area of $4.6 \mathrm{~m}^{2}$ to a 7-cm height using a self-propelled flail-type Carter $^{\mathrm{TM}}$ harvester (Carter MGF Co., Inc., Brookston, IN). A fresh forage sample of approximately $500 \mathrm{~g}$ was taken from each plot, weighed, dried at $55{ }^{\circ} \mathrm{C}$ to determine DM concentration, and then ground using a Wiley mill (standard model 4, Arthur H. Thomas Co., Philadelphia, PA) to pass through a 1$\mathrm{mm}$ screen. Nitrogen in ground forage samples was extracted using a method adapted from Isaac and Johnson (1976), and $\mathrm{N}$ was quantified using an automated continuous-flow injection analyzer (QuickChem 8000 FIA+, Lachat Instruments, Loveland, CO). The plant species composition was assessed in each plot at all cuts by handseparating a subsample of approximately $100 \mathrm{~g}$ into four categories: timothy, tall fescue, alfalfa, and others, and calculating the proportion of each species.

\section{Statistical analyses}

Statistical analyses were performed in SAS 9.4 (2013). Analyses of variance were performed using the MIXED procedure for all listed dependent variables: root length, root diameter, and biomass. Blocks and minirhizotron tubes were considered random effects, while management systems (CAN, SLU, and ALF), soil depth, and photo sessions were considered fixed effects. Photo sessions and soil depth were considered as repeated measurements. Structure of the covariance was modelled for every dependent variable. Normal data distribution was evaluated through the UNIVARIATE procedure (SAS Institute 2006), and the Shapiro-Wilk test (Shapiro and Wilk 1965) was used to determine the normality of the residuals distribution. The homogeneity of variance was verified visually with graphics of residuals. Differences were considered significant at $P \leq 0.05$.

A principal component analysis was performed using proportions of total root length in all diameter classes with the complete dataset of 2017. An analysis of variance was thereafter conducted on the scores of every combination of soil depth, photo session, and management system on axes 1 and 2 of the principal component analysis to assess how management system, time, and soil depth affected the root length distribution. To interpret significant triple interactions, the levels of two factors were fixed to compare the levels of the third factor.

\section{Results}

Aboveground growth and proportion of seeded species

The forage DM yield was affected by a significant interaction between management system and defoliation in both years (Fig. 1). The ALF management system yielded more than the SLU and CAN management systems at the third defoliation in both years. The forage DM yield of the SLU management system was lower than that of the other two management systems at the first defoliation in 2017, and lower than that of the ALF management system at the second defoliation in 2018.

The proportion of tall fescue in all management systems increased through defoliations in 2017 (24\%, $35 \%$, and $55 \%$ at $1 \mathrm{st}, 2 \mathrm{nd}$, and $3 \mathrm{rd}$ defoliations, respectively) and $2018(50 \%, 54 \%$, and $57 \%$ at 1 st, 2 nd, and 3rd defoliations, respectively) (Fig. 1). The proportion of alfalfa in the ALF management system increased through defoliations in 2017 (35\%, 45\%, and 67\% at $1 \mathrm{st}, 2 \mathrm{nd}$, and 3rd defoliations, respectively) and 2018 (51\%, $70 \%$, and $75 \%$ at 1 st, 2 nd, and 3rd defoliations, respectively) (Fig. 1).

Root elongation dynamics over the $0-60 \mathrm{~cm}$ soil profile

Root elongation rates in the two grass-only management systems (SLU and CAN) did not differ in any of the monitored periods (Table 4). Root elongation rates of all mixtures over the $60-\mathrm{cm}$ soil profile were the greatest in the spring of the first post-seeding year (2017, Table 4, Fig. 2a). Root elongation either stopped in the ALF management system or slowed down in the SLU and CAN management systems in the post-defoliation 1 period (Table 4, Fig. 2a). In the post-defoliation 2 period, root elongation rates of the SLU and CAN management systems did not change while root elongation resumed in the ALF management 
Fig. 1 Forage dry matter (DM) yield in three forage management systems (SLU, a mixture of timothy and tall fescue fertilized with dairy cattle slurry; CAN, a mixture of timothy and tall fescue fertilized with calcic ammonium nitrate and; ALF, a mixture of timothy, tall fescue, and alfalfa unfertilized during post-seeding years) at each defoliation event (1st, 2nd, or 3rd def.) in 2017 and 2018. Each bar includes the plant species composition of harvested forages at each defoliation. Different uppercase letters indicate significant differences in forage DM yield among combinations of management systems and defoliations within a year

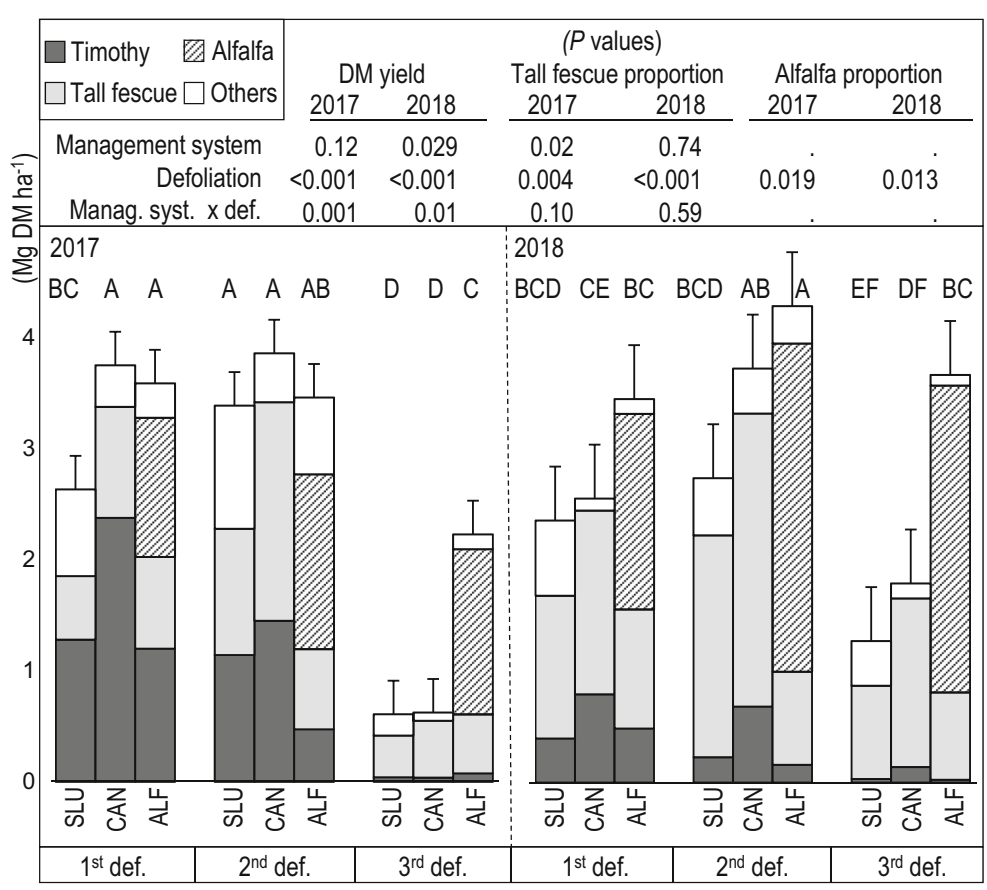

system (Table 4). In the post-defoliation 3 period, no root elongation was measured in any management systems (Table 4). In the fall, root length in all management systems decreased with time, but this decrease was greater in the SLU and CAN management systems than in the ALF management system (-18.7 vs. $-8.6 \mathrm{~mm}$ tube $^{-1}$ day $^{-1}$; Table 4).

In the spring of the second post-seeding year (2018), root elongation rates in the SLU and CAN management systems were reduced three-fold as compared to the same period in the first post-seeding year (2017; Table 4). The mean root diameter over the 60 -cm soil profile decreased continuously in 2017 , with no differences among the three forage management systems (Fig. 2b).

Overwinter changes in root length and diameter

Root length of the grass-only management systems (SLU and CAN) over the $60-\mathrm{cm}$ soil profile increased from the last photo session in fall to the first photo session the next spring in both winters of 2016-2017 (+113 mm tube $\left.{ }^{-1}\right)$ and 2017-2018 (+1037 mm tube ${ }^{-1}$; Table 5). The increase was significant in the $30-45$ and 45-60 cm soil layers in 2016-2017 and at all soil depths in 2017-2018 (Fig. 3). Root length in the ALF management system did not change over the first winter and decreased by $517 \mathrm{~mm}$ tube ${ }^{-1}$ over the second winter.
Average root diameter over the 60 -cm soil profile in all management systems increased more over the first than over the second winter period (Table 5).

Root length and biomass depth distribution

In Oct. 2016, 2017, and 2018, total root length (0-60 cm soil profile) was 425, 2164, and $1137 \mathrm{~mm} \mathrm{tube}^{-1}$ respectively (Fig. 4a-c), while total root biomass $(0-$ $45 \mathrm{~cm}$ soil profile) reached 4.1, 5.8, and 7.3 Mg DM ha $^{-1}$, respectively (Fig. $4 \mathrm{~d}-\mathrm{f}$ ).

Root length and root biomass measured in the fall varied with soil depth, but did not vary among the three management systems at any depth (Fig. 4). The distribution of root biomass in the soil profile was similar in all 3 years, with 73 to $75 \%$ of the biomass in the top $15 \mathrm{~cm}$ of soil (Fig. $4 \mathrm{~d}-\mathrm{f}$ ). The distribution of root length gradually shifted over the soil profile, and the proportion of root length in the surface soil layer $(0-15 \mathrm{~cm})$ decreased from $79 \%$ in 2016 to $29 \%$ in 2017 and $12 \%$ in 2018 (Fig. 4a-c).

\section{Root length distribution per diameter class}

The principal component analysis revealed that root length distribution among diameter classes changed with soil depth (spatial gradient) and among photo 
Table 4 Daily root elongation rates in three forage management systems (SLU, a mixture of timothy and tall fescue fertilized with dairy cattle slurry; CAN, a mixture of timothy and tall fescue fertilized with calcic ammonium nitrate and; ALF, a mixture of timothy, tall fescue, and alfalfa unfertilized during post-seeding years) during the first post-seeding year (2017) and the following spring (2018)

\begin{tabular}{|c|c|c|c|c|c|c|}
\hline & \multicolumn{5}{|l|}{2017} & \multirow{2}{*}{$\begin{array}{l}2018 \\
\text { Spring }\end{array}$} \\
\hline & Spring & Post-defoliation 1 & Post-defoliation 2 & Post-defoliation 3 & Fall & \\
\hline \multicolumn{7}{|c|}{ Elongation rate (mm tube ${ }^{-1}$ day $^{-1}$ ) } \\
\hline SLU & $34.4 \mathrm{a}$ & $11.0 \mathrm{~b}$ & $13.1 \mathrm{~b}$ & $-0.6 \mathrm{c}$ & $-18.2 \mathrm{~d}$ & $12.7 \mathrm{~b}$ \\
\hline CAN & $45.9 \mathrm{a}$ & $12.2 \mathrm{~b}$ & $10.6 \mathrm{~b}$ & $-3.2 \mathrm{a}$ & $-19.1 \mathrm{~d}$ & $12.5 \mathrm{~b}$ \\
\hline ALF & $32.0 \mathrm{a}$ & $-5.4 \mathrm{c}$ & $16.8 \mathrm{~b}$ & $2.0 \mathrm{c}$ & $-8.6 \mathrm{c}$ & \\
\hline \multicolumn{7}{|l|}{ Contrasts ( $P$ values $)$} \\
\hline SLU and CAN vs. ALF & 0.27 & 0.004 & 0.39 & 0.40 & 0.031 & \\
\hline SLU vs. CAN & 0.19 & 0.85 & 0.74 & 0.64 & 0.87 & 0.98 \\
\hline
\end{tabular}

Within a management system, values with the same letter are not statistically different at $P \leq 0.05$. Values in italics are not statistically different from 0. Spring periods started with the first N amendment (16 May 2017 and 10 May 2018) and stopped at the first defoliation (6 June 2017 and 2018); subsequent post-defoliation periods lasted 5 weeks ensuing a defoliation, while the fall period covered the rest of the growing season until 30 Nov. 2017

sessions (temporal gradient), but was not affected by management systems (Fig. 5). The spatial gradient indicated that while very fine roots $(<300 \mu \mathrm{m}$, first component) dominated near the soil surface $(0$ $30 \mathrm{~cm})$, coarser roots $(>300 \mu \mathrm{m}$, first component) dominated at greater depths. The temporal gradient

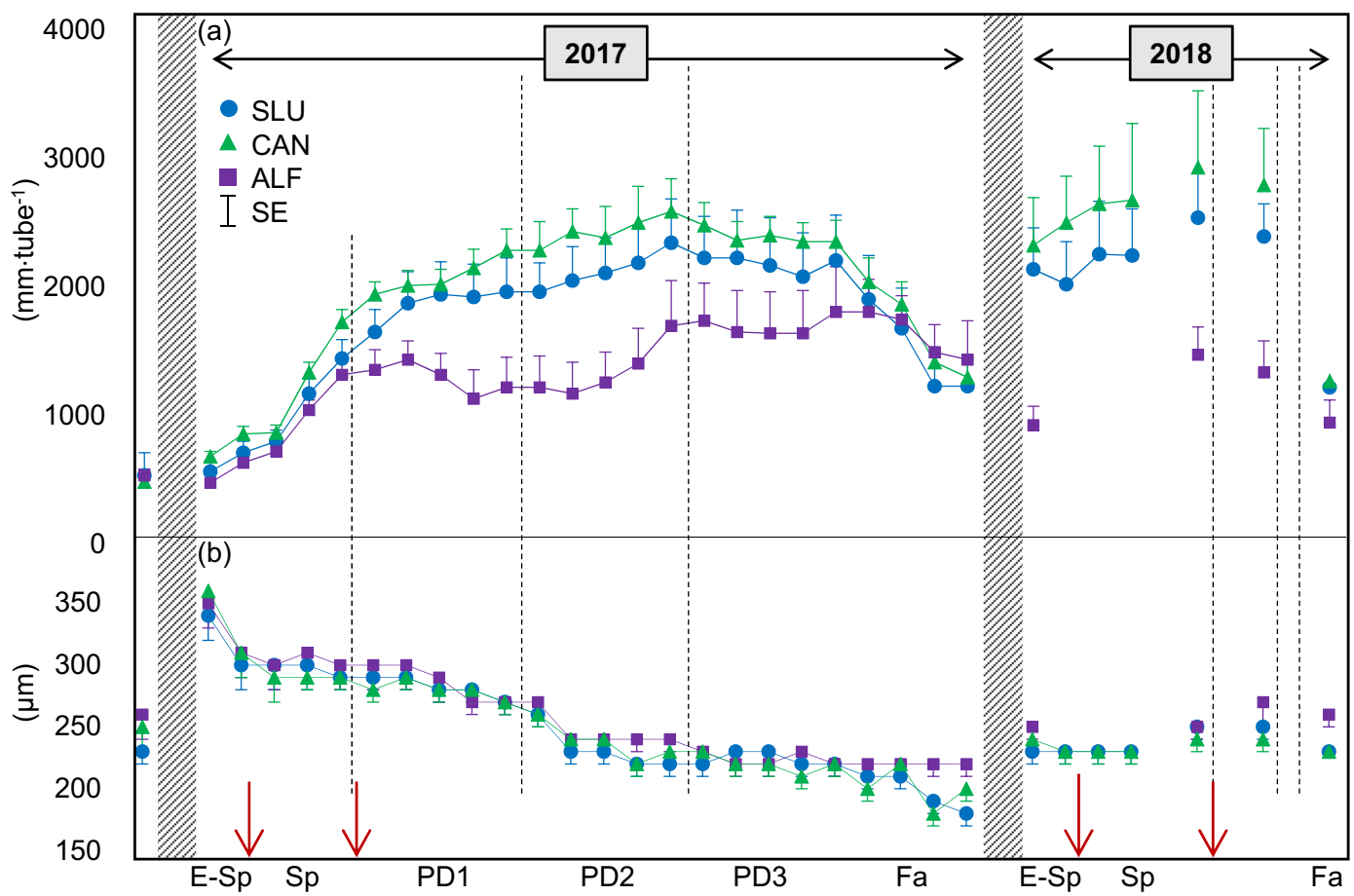

Fig. 2 Root length per tube (a) and average root diameter over the 0-60 $\mathrm{cm}$ soil profile (b) for each photo session from the fall of the seeding year in 2016 to the fall of 2018. SLU, a mixture of timothy and tall fescue fertilized with dairy cattle slurry; CAN, a mixture of timothy and tall fescue fertilized with calcic ammonium nitrate and; ALF, a mixture of timothy, tall fescue and alfalfa unfertilized during post-seeding years. Hatched zones indicate winter periods, dotted lines indicate defoliations, and arrows indicate fertilization events. Periods (E-Sp, early spring; Sp, spring; PD: postdefoliation; Fa, fall) were determined by defoliation events and $\mathrm{N}$ applications. For more details about periods, see Table 3A. Standard errors (SE) are presented for each photo session 
Table 5 Overwinter changes ${ }^{\mathrm{a}}$ in root length and diameter in grass-only (SLU and CAN) and grass-alfalfa (ALF) management systems

\begin{tabular}{|c|c|c|c|c|}
\hline & \multicolumn{2}{|l|}{ 2016-2017 } & \multicolumn{2}{|l|}{ 2017-2018 } \\
\hline & Mean \pm SE & $P$ value & Mean \pm SE & $P$ value \\
\hline \multicolumn{5}{|c|}{ Root length (mm tube ${ }^{-1}$ ) } \\
\hline SLU and $\mathrm{CAN}^{\mathrm{b}}$ & $+113 \pm 42.1$ & 0.017 & $+1037 \pm 126.3$ & $<0.002$ \\
\hline ALF & $-53 \pm 67.1$ & 0.450 & $-517 \pm 38.9$ & $<0.001$ \\
\hline \multicolumn{5}{|l|}{ Root diameter $(\mu \mathrm{m})$} \\
\hline SLU and CAN & $+110 \pm 22.8$ & $<0.001$ & $+48 \pm 21.0$ & 0.023 \\
\hline ALF & $+83 \pm 24.0$ & 0.008 & $+30 \pm 11.4$ & 0.031 \\
\hline
\end{tabular}

${ }^{\mathrm{a}}$ The change was calculated by subtracting the last value in fall from the first value in spring (4 Oct and 4 May in 2016-2017, and 30 Nov and 25 Apr. in 2017-2018); contrasts were used to determine the statistical significance of the change

${ }^{\mathrm{b}}$ Results are an average of the SLU (mixture of timothy and tall fescue fertilized with dairy cattle slurry) and CAN (mixture of timothy and tall fescue fertilized with calcic ammonium nitrate) forage management systems because there were no significant differences between those two management systems

indicated that roots were coarser in early spring, became progressively finer until mid-Oct., and coarser again $(>$ $300 \mu \mathrm{m})$ after mid-Oct.

There was a significant interaction between management systems, photo sessions (time), and soil depth $(P<0.001$, Fig. 5). Values of the first component were lower for the SLU than the CAN management system in early spring (until 12 May 2017), indicating a larger proportion of very fine roots $(<300 \mu \mathrm{m})$ in the SLU management system, for both $0-15$ and $15-30$ soil layers. For all management systems, the depth factor was significant in the early season only, meaning that root length distribution tended to homogenize over depth through time. This homogenization came earlier in the ALF management system (mid-Sept.) than in the SLU and CAN management systems (mid-Oct.).
Fig. 3 Overwinter root length changes in the grass-only management systems (SLU, a mixture of timothy and tall fescue fertilized with dairy cattle slurry and CAN, a mixture of timothy and tall fescue fertilized with calcic ammonium nitrate) for each 15 cm soil layer during the 20162017 and 2017-2018 winters. Asterisks indicate a significant $(P<0.05)$ change between fall and the following spring root length values, and standard errors are presented for each soil layer. Values are averaged across SLU and CAN forage management systems because they did not differ significantly

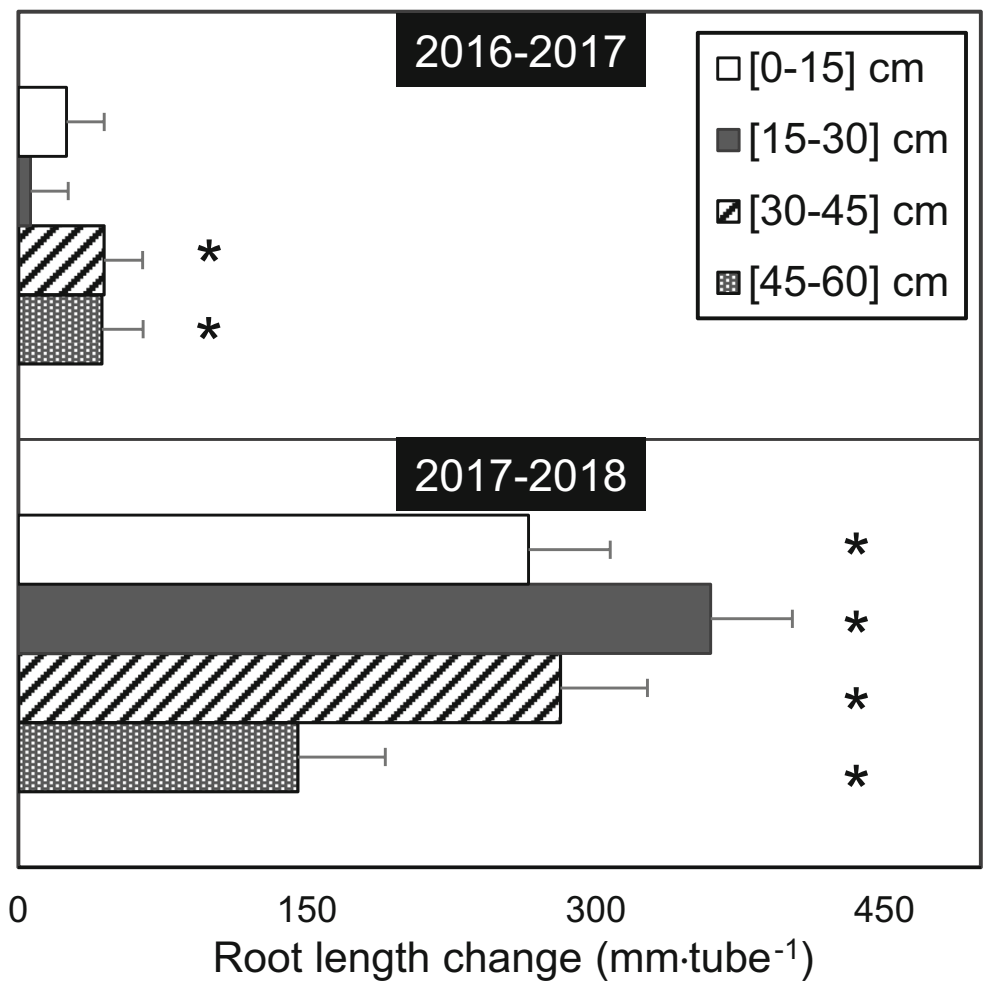


Fig. 4 Depth distribution of root length $(\mathbf{a}, \mathbf{b}, \mathbf{c})$ and root biomass $(\mathbf{d}, \mathbf{e}, \mathbf{f})$ in Oct. of 2016, 2017, and 2018. Values are averaged across all forage management systems (treatments) because they did not differ significantly. Standard errors are presented for each soil layer. Different letters indicate significant $(P<0.05)$ differences among soil depths. Root length was measured from minirhizotron images to a $60-\mathrm{cm}$ depth, while root biomass resulted from soil coring to a $45-\mathrm{cm}$ depth

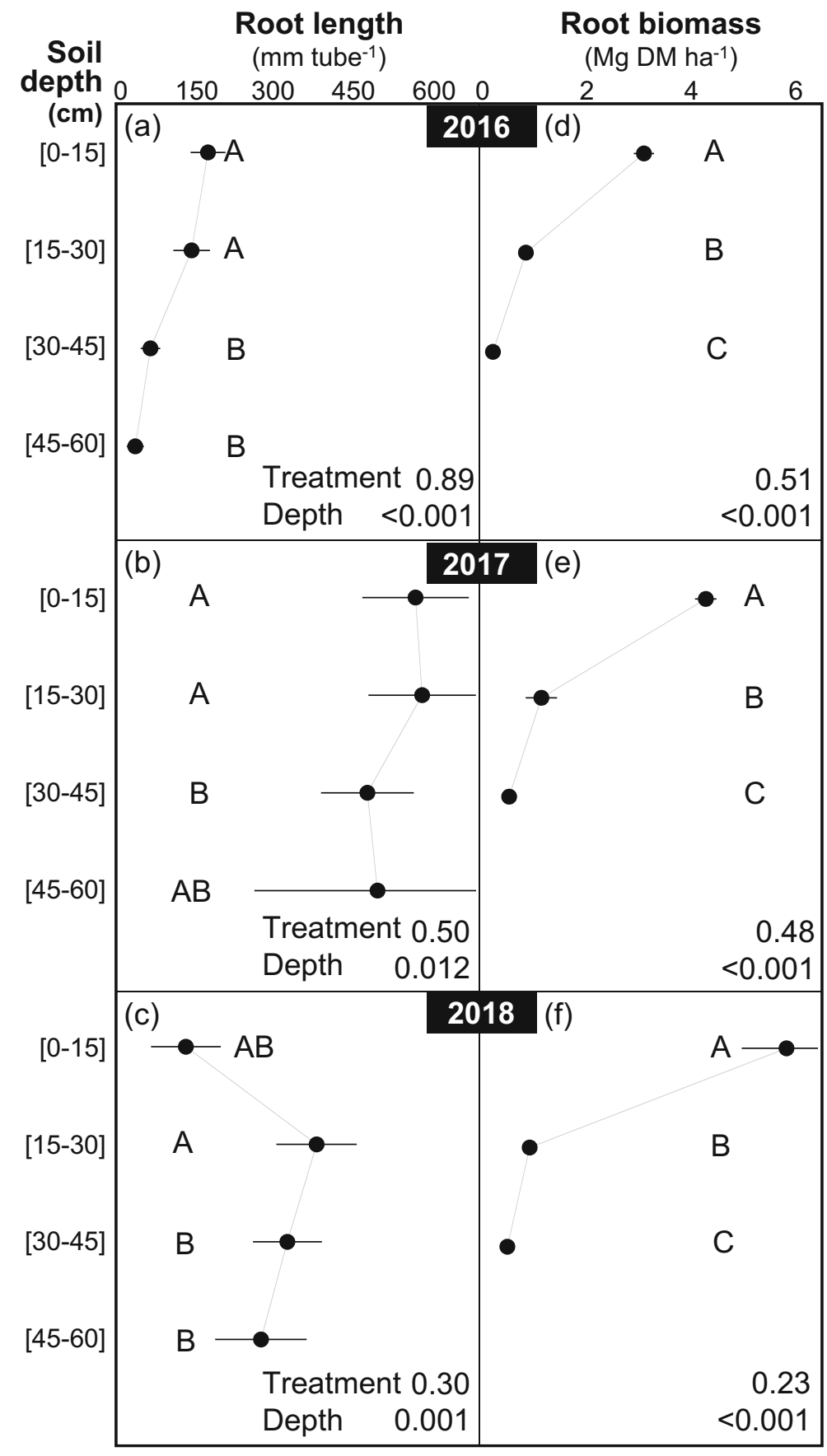

Root mortality and turnover

In the ALF management system, no signs of root mortality were observed at any soil depth $(P>0.05)$, thus, the root length turnover could not be calculated for this management system. In the SLU and CAN management systems, root mortality assessed until late fall totalled
1000 to $1137 \mathrm{~mm}$ tube ${ }^{-1}$ over the $0-60 \mathrm{~cm}$ soil profile in the first post-seeding year (2017). It decreased with depth (Fig. 6; $P<0.001$ ), from an average of $391 \mathrm{~mm}$ tube $\mathrm{e}^{-1}$ in the top $15 \mathrm{~cm}$ of soil to $83 \mathrm{~mm}$ tube $^{-1}$ in the 45-60 cm soil layer. Root length turnover based on the late fall estimate averaged $131 \%$ over the $0-60 \mathrm{~cm}$ soil profile and was affected by an interaction between soil 
depth and management system $(P=0.002)$. In the 0 $15 \mathrm{~cm}$ soil layer, root length turnover was greater in the SLU than in the CAN management system (269 vs. $138 \%, P<0.05$; Fig. 6), while it was similar between management systems in the deeper soil layers with average values of $149 \%, 107 \%$, and $58 \%$ in the $15-30$, $30-45$ and 45-60-cm soil layers, respectively (Fig. 6). If assessed until early fall, root mortality in the SLU and CAN management systems totalled 263 to $354 \mathrm{~mm}$ tube $^{-1}$ over the $0-60 \mathrm{~cm}$ soil profile (data not shown), resulting in a root length turnover that averaged $23 \%$.

\section{Discussion}

Early spring root growth

The large overwinter increase in grass root length observed in the present study suggests that grass root growth resumed very early in spring, likely before shoot growth. In line with this finding, Rytter and Rytter (2012) previously suggested that roots of perennial crops are not dormant between growing seasons, and that root growth never completely ceases. In perennial forage crops, shoot growth is generally assumed to resume concomitantly when air temperature has reached an average of $0{ }^{\circ} \mathrm{C}$ for 5 or 6 consecutive days for forage grasses like timothy and tall fescue, and $5{ }^{\circ} \mathrm{C}$ for alfalfa (Jégo et al. 2013, 2015; Qian et al. 2010). In spring 2017, these requirements were reached 1 month before the first photo session and, therefore, it is not possible to ascertain if the measured overwinter increase in root length occurred before shoot growth. In 2018, however, the temperature requirement for shoot growth of grasses was reached only 6 days prior to the first photo session (25 Apr.) when a major increase in root length was measured $\left(+1037 \mathrm{~mm}\right.$ tube $\left.{ }^{-1}\right)$. Considering a root elongation rate of $12.6 \mathrm{~mm}$ tube ${ }^{-1}$ day $^{-1}$ during this period (Table 4), it can reasonably be assumed that root growth resumed long before shoot growth. Although an increase in root length of $1037 \mathrm{~mm}$ tube ${ }^{-1}$ may appear impressive, it consisted mainly of an increase in length of very fine roots, and probably did not represent a large proportion of the total root biomass. Our data, however, do not allow the estimation of early spring changes in root biomass.

In arctic environments, roots of perennial grasses remain active and able to absorb nutrients, especially $\mathrm{N}$, during the snowmelt period (Bilbrough et al. 2000;
Edwards and Jefferies 2010; Ma et al. 2018a). Moreover, $\mathrm{NO}_{3}{ }^{-}$and $\mathrm{NH}_{4}{ }^{+}$are reported to accumulate in snow-covered soils (Tatti et al. 2014) as mineralization, nitrification, and denitrification occur in Canadian agricultural soils during winter (Chantigny et al. 2019; Clark et al. 2009). As root growth is responsive to $\mathrm{N}$ availability (Huang and Eissenstat 2000; Hodge 2004), the likely presence of available $\mathrm{N}$ in soils in early spring could partly explain the root elongation of grasses under cold conditions. We suggest that to exploit this available $\mathrm{N}$, de novo root growth likely occurs using $\mathrm{C}$ resources stored in standing roots, as photosynthesis has not yet resumed.

The increase in root diameter over both winter periods in all treatments could be the result of the growth of large roots or/and the mortality of fine roots. Even a small change in root diameter has major consequences in terms of soil exploration and nutrient acquisition (Ma et al. 2018b). In the grass-only management systems, the large increase in root diameter found in the first winter after establishment supports the idea that, at this period, root development is mainly aimed at increasing energy and nutrient storage capacity, hence the larger roots. In subsequent winter periods, however, root development is mainly dedicated to the renewal of the root system. Traits displayed are then more closely related to an acquisitive strategy, i.e. surface rooting, high root length density, and high root $\mathrm{N}$ concentration (Mommer et al. 2011), hence the finer roots. Since there was no apparent root growth over winter periods in the grass-alfalfa mixture (ALF), it is reasonable to believe that the small overwinter increase in average root diameter in this treatment is related to the mortality of fine roots.

In-season root elongation and depth distribution patterns

The observed slower root elongation in the regrowth periods following the first defoliation is consistent with a previous observation in grass-clover swards (Chen et al. 2016), which was explained by a lower watersoluble carbohydrate availability for root growth in the regrowth periods following defoliation, compared to the primary growth. However, higher root growth rates during summer than spring were reported from a study conducted with tall fescue in France (Bélanger et al. 1994), which is contrary to our observations.

Seasonal variations in root length and diameter of the grass-only management systems (SLU and CAN) over 


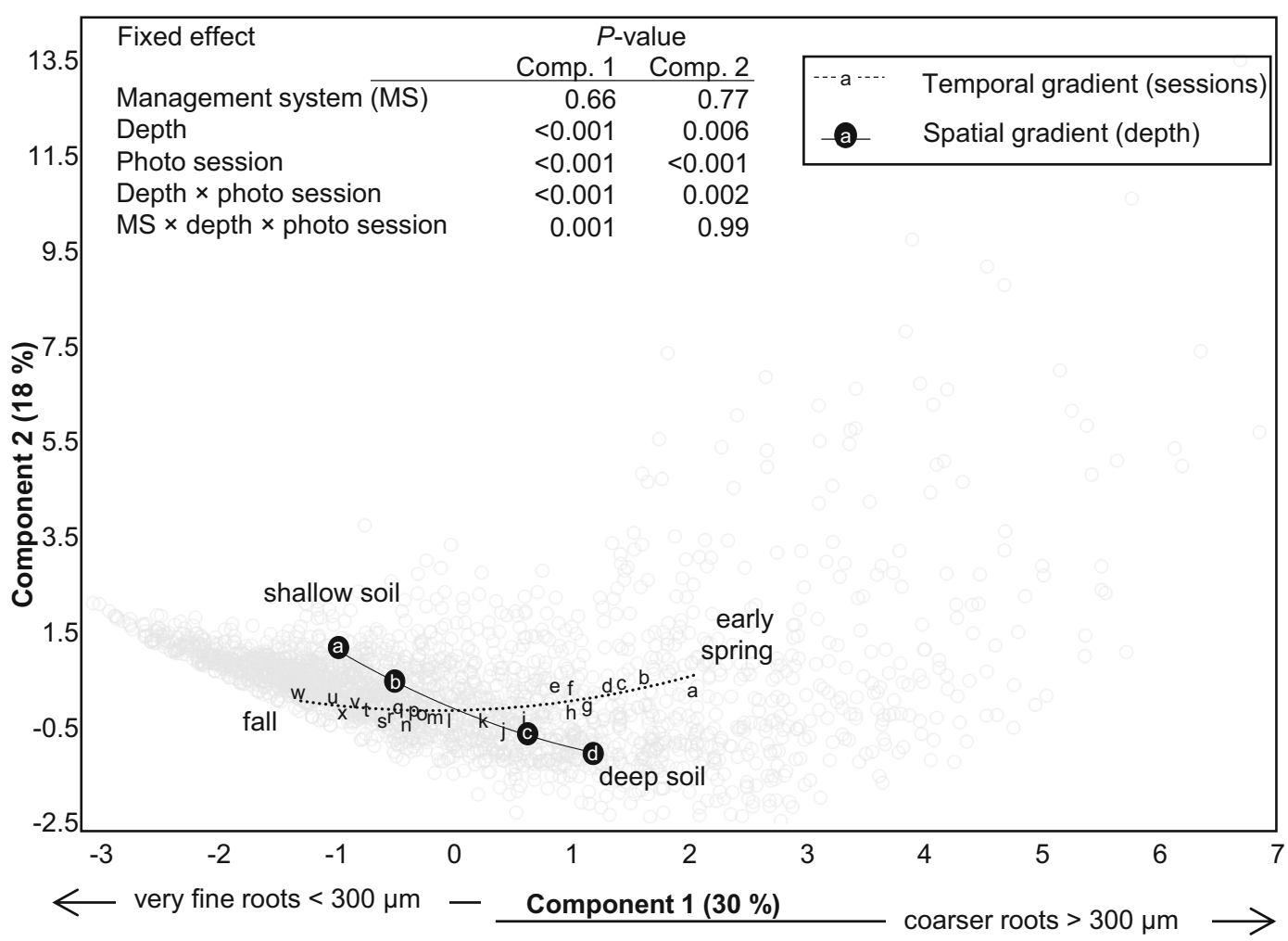

Fig. 5 Diagram illustrating the relationships between the root length distribution in 10 diameter classes ranging from 0 to $>900 \mu \mathrm{m}$ and forage management systems, soil depth, and photo sessions in 2017. Scatterplot in the background is the score of every combination of soil depth, photo session, and forage management system for components 1 and 2 . The analyses of variance

the $60-\mathrm{cm}$ soil profile are consistent with those reported under similar conditions in shallower soil layers (0-30 to 0-40 cm; Beyrouty et al. 1990; Chen et al. 2016), suggesting that deep root development $(30-60 \mathrm{~cm})$ also shows a seasonal pattern. The observed patterns in root length over two growing seasons is also similar to those observed for root biomass by Steen (1989).

Root elongation patterns differed between the management system with alfalfa and the management systems without alfalfa. This could be due at least partially to phenological rooting differences between grasses and legumes (Bolinder et al. 2002; Fan et al. 2016). In pure alfalfa stands, defoliation stops root elongation, increases decay, and thus stimulates root turnover (Goins and Russelle 1996; Reid et al. 2015). This is partly in line with our results showing a cessation of root elongation from the first defoliation in the management system with alfalfa, while root elongation continued in the grass-only management systems. However, we did not observe an increase in root decay or a higher root were conducted on these scores ( $P$ values shown). Letters in alphabetical order show the evolution of root length distribution along temporal (a to $\mathrm{x}, 24$ photo sessions) and spatial (a to d, 4 sampling depths) gradients, for the scores (1 and 2) averaged over every photo session and soil depth. Arrows show results of the correlation factors of component 1

turnover with alfalfa. In the fall, the greater root mortality found in the grass-only management systems could be related to differences between monocotyledons and dicotyledons; tap roots of legumes are longer-lived because of large root diameter and high dry matter content (Hakl et al. 2017). Besides, grass-only management systems were $\mathrm{N}$ fertilized in surface soil, while the mixture with alfalfa was not. As high nutrient availability in shallow soil layers tend to trigger soil exploration by fine roots and result in high specific root length (Mommer et al. 2011; Prieto et al. 2015), fertilization could have stimulated the growth of finer roots in the surface soil in the SLU and CAN management systems, contributing to their higher root elongation rates after the first defoliation. The present experimental design does not allow to decouple the effect of plant species composition from that of fertilization.

The grass-only management systems (SLU and CAN) did not differ in total root length and biomass. Chantigny et al. (2007) reported similar forage DM 


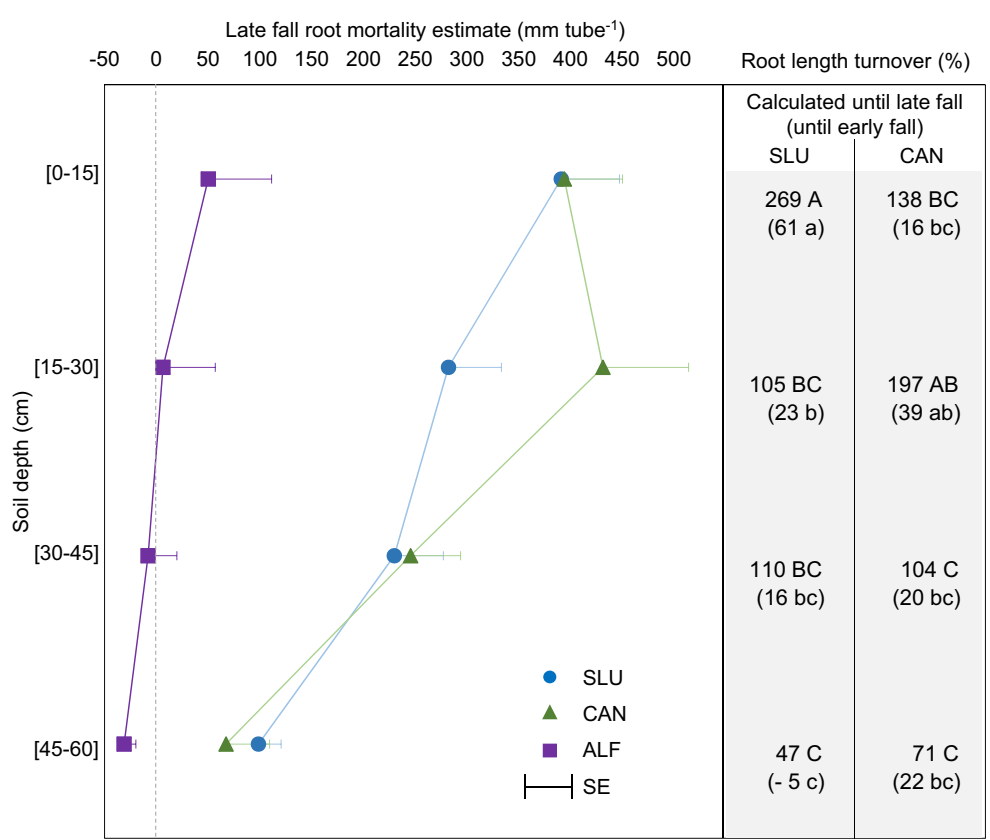

Fig. 6 Root mortality ( $\mathrm{mm}$ per tube) in the first post-seeding year (2017) of all management systems (SLU, a mixture of timothy and tall fescue fertilized with dairy cattle slurry; CAN, a mixture of timothy and tall fescue fertilized with calcic ammonium nitrate and; ALF, a mixture of timothy, tall fescue and alfalfa unfertilized during post-seeding years), along with root length turnover of the

yield for timothy with mineral fertilizer and animal slurries in the area of our study. It is hypothesized that mineralization of slurry organic $\mathrm{N}$ as the season progressed contributed to crop nutrition, thereby attenuating the discrepancy between these two forage management systems. Moreover, mineralization of the soil $\mathrm{N}$ reserve also likely contributed significantly to forage nutrition (Nyiraneza et al. 2010), thus further mitigating the difference in $\mathrm{N}$ availability between dairy cattle slurry and mineral fertilizers.

The dissimilar depth distributions between root length and root biomass in the soil profile were unexpected, especially because increases in root biomass mostly occurred in the $0-15 \mathrm{~cm}$ soil layer as sward aged, as also reported by Bolinder et al. (2002). Nevertheless, Fort et al. (2017) found that, in many species, root tissue density tends to decrease with depth while root diameter increases, a strategy aimed at maximising water uptake. As the demand for water increases during summer and it becomes scarcer, deep coarse rooting maximises water uptake and transport from the subsoil to shoots over the long-term (Fort et al. 2017; Klimesova et al. 2018).
SLU and CAN management systems calculated until late fall or until early fall in brackets. Letters show differences among soil depths and management systems for the root length turnover calculated until late fall (upper case letters) or early fall (lower case letters)

These deep roots can survive over a long period, as they are protected from degradation and external conditions in the deep soil (Rasse et al. 2005). In the present study, this could explain why a large proportion of root length but a low proportion of root biomass were found in the 15-30 and 30-45 cm soil layers in 2017 and 2018 . However, root length and biomass were obtained from two different methods and, therefore, depth distributions of these parameters cannot be compared.

Root length turnover and implications for soil C storage

Several factors may explain the higher turnover rate observed in the surface soil layer than at depth in the present study. Indeed, a greater oxygen availability, water availability, and temperature near the soil surface can lead to a greater respiration and decomposability of roots in this soil layer (Gill et al. 1999; Prieto et al. 2016; Wu et al. 2013). In the present study, the surface-applied $\mathrm{N}$ fertilizer is also thought to have fostered the growth of very fine and absorptive roots in surface soil layers, as $\mathrm{N}$ availability entails intense root exploration of the topsoil 
at a very low C cost (Eissenstat 1992). However, these absorptive fine roots are short-lived and highly decomposable (Roumet et al. 2016), which is consistent with the high root length turnover that was found near the soil surface. Turnover values of the present study are also in line with the suite of traits that Prieto et al. (2015) observed at the community level, i.e. fine, low-lignin, high-N, highly acquisitive roots, and with great soil exploration capacity in shallow soil layers. Regarding root traits in deep soil layers, many studies stated that large root diameter and longevity are positively correlated for a wide range of plant species (Gill et al. 2002; Roumet et al. 2016; Weemstra et al. 2016; Wu et al. 2013), which is consistent with our results of larger diameter and lower root turnover rate at depth. Some authors, however, argue for a more complex relationship between diameter and longevity (McCormack et al. 2015; McCormack and Guo 2014). Difference in root turnover rates between the grass-only management systems (SLU and CAN) was significant only in the topsoil layer. Since root mortality did not differ between management systems, this difference in root turnover is mostly attributable to the lower root length in the fall for the SLU management system.

Root turnover (Goss and Watson 2003) and rooting depth (Rasse et al. 2005; Poirier et al. 2018) have been identified as key drivers of $\mathrm{C}$ storage potential. On one side, the high root turnover rate observed in the surface soil layer in the present study for the grass-only management systems can favor $\mathrm{C}$ storage by providing readily decomposable litter which can be rapidly transformed to soil microbe products that contribute to the formation of soil organic matter and C storage (Cotrufo et al. 2013; Poirier et al. 2018). In accordance, soil C accumulation was shown to decrease with soil depth under perennial pasture (Ojeda et al. 2017). On the other side, deep roots rich in recalcitrant compounds such as lignin and with a high mean residence time in soil (Rumpel and Kögel-Knabner 2011) are also crucial for long-term soil organic matter stabilization (Poirier et al. 2018). Indeed, our results highlight that the studied forage management systems, including the mixture with alfalfa, invested in coarse root development in deep soil layers $(30-60 \mathrm{~cm})$ at early stages of the sward establishment. Moreover, the results showed low root length turnover at depth, suggesting a preservation of coarseroot $\mathrm{C}$. Although $\mathrm{C}$ inputs were not measured in this study, it could be suggested that $\mathrm{C}$ input and $\mathrm{C}$ storage potential in deep soil layers occurred early and nearly peaked by the end of the first post-seeding year. Further research is needed to confirm this hypothesis, which could have strong implications in the context of short grassland-annuals rotation systems.

Root length turnover values calculated until late fall are greater than those calculated until early fall (Fig. 6). Root mortality is likely to have increased between early and late fall root measurements. It is not excluded, however, that soil displacement around observation tubes at this period of the year might have led to an overestimation of late fall root mortality and the corresponding root turnover. Indeed, our silty clay soil is susceptible to shrink-swell behaviour with varying soil water content and freeze-thaw cycles. We observed that some roots disappeared from the observation tubes in late fall, when soil water content was high, and reappeared later in the subsequent spring, after soil had dried. It was not possible to quantify this observation and, therefore, root length turnover was also presented based on early fall measurements, at which point the soil was not yet affected by shrink-swell behaviour.

\section{Conclusions}

This study improves our understanding of many important drivers of $\mathrm{C}$ dynamics in soils under perennial crops, especially those affecting $\mathrm{C}$ inputs such as root elongation, mortality, turnover, and depth distribution. The forage management system with alfalfa resulted in a slower root elongation after the first defoliation and a slower root mortality in the fall. In all management systems, roots were finer and more abundant near the soil surface than at depth, and grass-only management systems showed a decreasing root length turnover rate from the top soil layer to the $45-60 \mathrm{~cm}$ soil layer. Our results suggest that these spatial and temporal variations could impact root-derived C-input potential of perennial forage mixtures under different management systems.

Root growth and mortality were more contrasted between forage management systems that differed by the presence or absence of alfalfa than by the source of fertilization in grasses. The choice of perennial species in mixtures therefore appears as a key management factor for sustainable farming systems. Further research is required to assess root length turnover over multiple years along with in situ monitoring of soil organic $\mathrm{C}$. 
Acknowledgments This research was supported by Agriculture and Agri-Food Canada. The senior author gratefully acknowledges the support of Mitacs Globalink for a fellowship. The authors warmly thank $\mathrm{C}$. Lachance for her help and dedication to this project. We would also like to thank A. Bélanger, N. Bertrand, R. Morissette and J. Vachon for their ingenuity in the implementation of root observation devices, Q. Beaumard, M.-J. Boucher, A. Brégard, H. Bugaut, M. Hénaut, E. Lachapelle, R. Moussa and A. Perreault for their meticulous work in taking or processing root images, and A.-D. Baillargeon, G. Lévesque, J. Tremblay, and A. Robichaud for their assistance during field and laboratory work. The authors express their gratitude to Dr. Vincent Poirier for his timely comments on an earlier version of this article.

Open Access This article is licensed under a Creative Commons Attribution 4.0 International License, which permits use, sharing, adaptation, distribution and reproduction in any medium or format, as long as you give appropriate credit to the original author(s) and the source, provide a link to the Creative Commons licence, and indicate if changes were made. The images or other third party material in this article are included in the article's Creative Commons licence, unless indicated otherwise in a credit line to the material. If material is not included in the article's Creative Commons licence and your intended use is not permitted by statutory regulation or exceeds the permitted use, you will need to obtain permission directly from the copyright holder. To view a copy of this licence, visit http://creativecommons.org/licenses/by/4.0/.

\section{References}

Baldi E, Toselli M, Eissenstat D, Marangoni B (2010) Organic fertilization leads to increased peach root production and lifespan. Tree Physiol 30:1373-1382

Bardgett RD, Mommer L, De Vries FT (2014) Going underground: root traits as drivers of ecosystem processes. Trends Ecol Evol 29:692-699. https://doi.org/10.1016/j. tree.2014.10.006

Bélanger G, Gastal F, Warembourg F (1994) Carbon balance of tall fescue (Festuca arundinacea Schreb.): effects of nitrogen fertilization and the growing season. Ann Bot 74:653-659. https://doi.org/10.1006/anbo.1994.1167

Beyrouty CA, West CP, Gbur EE (1990) Root development of bermudagrass and tall fescue as affected by cutting interval and growth regulators. Plant Soil 127:23-30

Bilbrough CJ, Welker JM, Bowman WD (2000) Early spring nitrogen uptake by snow-covered plants: a comparison of arctic and alpine plant function under the snowpack. Arct Antarct Alp Res 32:404-411

Bolinder MA, Angers DA, Bélanger G, Michaud R, Laverdière MR (2002) Root biomass and shoot to root ratios of perennial forage crops in eastern Canada. Can J Plant Sci 82:731-737

Bolinder MA, Kätterer T, Andrén O, Parent LE (2012) Estimating carbon inputs to soil in forage-based crop rotations and modeling the effects on soil carbon dynamics in a Swedish long-term field experiment. Can J Soil Sci 92:821-833. https://doi.org/10.4141/cjss2012-036
Chantigny MH, Angers DA, Rochette P, Bélanger G, Massé D, Côté D (2007) Gaseous nitrogen emissions and forage nitrogen uptake on soils fertilized with raw and treated swine manure. J Environ Qual 36:1864-1872. https://doi. org/10.2134/jeq2007.0083

Chantigny MH, Bittman S, Larney FJ, Lapen D, Hunt DE, Goyer C, Angers DA (2019) A multi-region study reveals high overwinter loss of fall-applied reactive nitrogen in cold and frozen soils. Can J Soil Sci 99:1-10

Chen SM, Lin S, Loges R, Reinsch T, Hasler M, Taube F (2016) Independence of seasonal patterns of root functional traits and rooting strategy of a grass-clover sward from sward age and slurry application. Grass Forage Sci 71:607-621. https://doi.org/10.1111/gfs.12222

Chen Y, Camps-Arbestain M, Shen Q, Singh B, Cayuela ML (2018) The long-term role of organic amendments in building soil nutrient fertility: a meta-analysis and review. Nutr Cycl Agroecosyst 111:103-125. https://doi.org/10.1007/s10705017-9903-5

Clark K, Chantigny MH, Angers DA, Rochette P, Parent L-É (2009) Nitrogen transformations in cold and frozen agricultural soils following organic amendments. Soil Biol Biochem 41:348-356. https://doi.org/10.1016/j.soilbio.2008.11.009

Cotrufo MF, Wallenstein MD, Boot CM, Denef K, Paul E (2013) The microbial efficiency-matrix stabilization (MEMS) framework integrates plant litter decomposition with soil organic matter stabilization: do labile plant inputs form stable soil organic matter? Glob Chang Biol 19:988-995. https://doi.org/10.1111/gcb.12113

CRAAQ (2010) Guide de référence en fertilisation, 2e edn. Centre de référence en agriculture et agroalimentaire du Québec

Dawson LA, Thornton B, Pratt SM, Paterson E (2004) Morphological and topological responses of roots to defoliation and nitrogen supply in Lolium perenne and Festuca ovina. New Phytol 161:811-818. https://doi.org/10.1111 /j.1469-8137.2004.00979.x

De Deyn GB, Cornelissen JH, Bardgett RD (2008) Plant functional traits and soil carbon sequestration in contrasting biomes. Ecol Lett 11:516-531

Edwards KA, Jefferies RL (2010) Nitrogen uptake by Carex aquatilis during the winter-spring transition in a low Arctif wet meadow. J Ecol 98:737-744. https://doi.org/10.1111 /j.1365-2745.2010.01675.x

Eissenstat DM (1992) Costs and benefits of constructing roots of small diameter. J Plant Nutr 15:763-782. https://doi. org/10.1080/01904169209364361

Fan J, McConkey B, Wang H, Janzen H (2016) Root distribution by depth for temperate agricultural crops. Field Crop Res 189:68-74. https://doi.org/10.1016/j.fcr.2016.02.013

Faucon M-P, Houben D, Lambers H (2017) Plant functional traits: soil and ecosystem services. Trends Plant Sci 22(5):385-394. https://doi.org/10.1016/j.tplants.2017.01.005

Fort F, Cruz P, Lecloux E, Bittencourt de Oliveira L, Stroia C, Theau JP, Jouany C (2016) Grassland root functional parameters vary according to a community-level resource acquisition-conservation trade-off. J Veg Sci 27:749-758. https://doi.org/10.1111/jvs. 12405

Fort F, Volaire F, Guilioni L, Barkaoui K, Navas ML, Roumet C (2017) Root traits are related to plant water-use among rangeland Mediterranean species. Funct Ecol 31:17001709. https://doi.org/10.1111/1365-2435.12888 
Freschet G, Roumet C, Treseder K (2017) Sampling roots to capture plant and soil functions. Funct Ecol 31:1506-1518. https://doi.org/10.1111/1365-2435.12883

Ghafoor A, Poeplau C, Kätterer T (2017) Fate of straw- and rootderived carbon in a Swedish agricultural soil. Biol Fertil Soils 53:257-267. https://doi.org/10.1007/s00374-016-1168-7

Gill RA, Burke IC, Milchunas DG, Lauenroth WK (1999) Relationship between root biomass and soil organic matter pools in the Shortgrass steppe of eastern Colorado. Ecosystems 2:226-236. https://doi.org/10.1007 /s100219900070

Gill RA, Burke IC, Lauenroth WK, Milchunas DG (2002) Longevity and turnover of roots in the shortgrass steppe: influence of diameter and depth. Plant Ecol 159:241-251. https://doi.org/10.1023/A:1015529507670

Goins GD, Russelle MP (1996) Fine root demography in alfalfa (Medicago sativa L.). Plant Soil 185:281-291. https://doi. org/10.1007/BF02257534

Goss MJ, Watson CA (2003) The importance of root dynamics in cropping systems research. J Crop Prod 8:127-155. https://doi.org/10.1300/J144v08n01_06

Gregory PJ, Atkinson CJ, Bengough AĞ, Else MA, FernándezFernández F, Harrison RJ, Schmidt S (2013) Contributions of roots and rootstocks to sustainable, intensified crop production. J Exp Bot 64:1209-1222. https://doi.org/10.1093 /jxb/ers385

Hakl J, Pisarčik M, Hrevušová Z, Šantrůček J (2017) In-field lucerne root morphology traits over time in relation to forage yield, plant density, and root disease under two cutting managements. Field Crop Res 213:109-117. https://doi. org/10.1016/j.fcr.2017.07.017

Hernandez P, Picon-Cochard C (2016) Presence of Trifolium repens promotes complementarity of water use and $\mathrm{N}$ facilitation in diverse grass mixtures. Front Plant Sci 7:538. https://doi.org/10.3389/fpls.2016.00538

Hodge A (2004) The plastic plant: root responses to heterogeneous supplies of nutrients. New Phytol 162:9-24. https://doi. org/10.1111/j.1469-8137.2004.01015.x

Huang B, Eissenstat DM (2000) Root plasticity in exploiting water and nutrient heterogeneity. In: Wilkinson RE (ed) Plantenvironment interactions, 2nd edn. Marcel Dekker, Georgia, pp 111-132

Ingram KT, Leers GA (2001) Software for measuring root characters from digital images. Agron J 93:918-922

Isaac RA, Johnson WC (1976) Determination of total nitrogen in plant tissue, using a block digestor. J Assoc Off Anal Chem

Jégo G, Bélanger G, Tremblay GF, Jing Q, Baron VS (2013) Calibration and performance evaluation of the STICS crop model for simulating timothy growth and nutritive value. Field Crop Res 151:65-77. https://doi.org/10.1016/j. fcr.2013.07.003

Jégo G, Rotz CA, Bélanger G, Tremblay GF, Charbonneau É, Pellerin D (2015) Simulating forage crop production in a northern climate with the integrated farm system model. Can J Plant Sci 95:745-757. https://doi.org/10.4141/cjps2014-375

Jensen ES, Peoples MB, Boddey RM, Gresshoff PM, HauggaardNielsen H, Alves BJR, Morrisson MJ (2012) Legumes for mitigation of climate change and the provision of feedstock for biofuels and biorefineries. A review. Agron Sustain Dev 32:329-364. https://doi.org/10.1007/s13593-011-0056-7
Klimesova J, Martinkova J, Ottaviani G (2018) Belowground plant functional ecology: towards an integrated perspective. Funct Ecol 32:2115-2126. https://doi.org/10.1111/13652435.13145

Kramer-Walter KR, Laughlin DC (2017) Root nutrient concentration and biomass allocation are more plastic than morphological traits in response to nutrient limitation. Plant Soil 416: 539-550. https://doi.org/10.1007/s11104-017-3234-9

Lazicki PA, Liebman M, Wander MM (2016) Root parameters show how management alters resource distribution and soil quality in conventional and low-input cropping systems in Central Iowa. PLoS One 11:e0164209

Lüscher A, Mueller-Harvey I, Soussana JF, Rees RM, Peyraud JL (2014) Potential of legume-based grassland-livestock systems in Europe: a review. Grass Forage Sci 69:206-228. https://doi.org/10.1111/gfs.12124

Ma L, Liu G, Xu X, Xin X, Bai W, Zhang L, Chen S, Wang R (2018a) Nitrogen acquisition strategies during the winterspring transitional period are divergent at the species level yet convergent at the ecosystem level in temperate grasslands. Soil Biol Biochem 122:150-159. https://doi. org/10.1016/j.soilbio.2018.04.020

Ma ZQ, Guo DL, Xu XL, Lu MZ, Bardgett RD, Eissenstat DM, McCormack ML, Hedin LO (2018b) Evolutionary history resolves global organization of root functional traits. Nature 555:94-97. https://doi.org/10.1038/nature25783

Martin AR, Isaac ME (2015) Plant functional traits in agroecosystems: a blueprint for research. J Appl Ecol 52: 1425-1435. https://doi.org/10.1111/1365-2664.12526

McCormack ML, Guo D (2014) Impacts of environmental factors on fine root lifespan. Front Plant Sci 5:205. https://doi. org/10.3389/fpls.2014.00205

McCormack ML, Dickie IA, Eissenstat DM, Fahey TJ, Fernandez CW, Guo D, Helmisaari HS, Hobbie EA, Iversen CM, Jackson RB, Leppälammi-Kujansuu J, Norby RJ, Phillips RP, Pregitzer KS, Pritchard SG, Rewald B, Zadworny M (2015) Redefining fine roots improves understanding of below-ground contributions to terrestrial biosphere processes. New Phytol 207:505-518. https://doi.org/10.1111 /nph.13363

McInenly LE, Merrill EH, Cahill JF, Juma NG (2010) Festuca campestris alters root morphology and growth in response to simulated grazing and nitrogen form. Funct Ecol 24:283292. https://doi.org/10.1111/j.1365-2435.2009.01642.x

Mommer L, Visser EJW, van Ruijven J, de Caluwe H, Pierik R, de Kroon H (2011) Contrasting root behaviour in two grass species: a test of functionality in dynamic heterogeneous conditions. Plant Soil 344:347-360. https://doi.org/10.1007 /s11104-011-0752-8

Nyfeler D, Huguenin-Elie O, Suter M, Frossard E, Lüscher A (2011) Grass-legume mixtures can yield more nitrogen than legume pure stands due to mutual stimulation of nitrogen uptake from symbiotic and non-symbiotic sources. Agric Ecosyst Environ 140:155-163. https://doi.org/10.1016/j. agee.2010.11.022

Nyiraneza J, Chantigny MH, N'Dayegamiye A, Laverdière MR (2010) Long-term manure application and forages reduce nitrogen fertilizer requirements of silage corn-cereal cropping systems. Agron J 102:1244-1251. https://doi. org/10.2134/agronj2009.0480 
Ojeda JJ, Caviglia OP, Agnusdei MG (2017) Vertical distribution of root biomass and soil carbon stocks in forage cropping systems. Plant Soil 423:175-191. https://doi.org/10.1007 /s11104-017-3502-8

Poeplau C, Zopf D, Greiner B, Geerts R, Korvaar H, Thumm U, Don M, Heidkamp A, Flessa H (2018) Why does mineral fertilization increase soil carbon stocks in temperate grasslands? Agric Ecosyst Environ 265:144-155. https://doi. org/10.1016/j.agee.2018.06.003

Poirier V, Roumet C, Munson AD (2018) The root of the matter: linking root traits and soil organic matter stabilization processes. Soil Biol Biochem 120:246-259. https://doi. org/10.1016/j.soilbio.2018.02.016

Prieto I, Roumet C, Cardinael R, Dupraz C, Jourdan C, Kim JH, Maeght JL, Mao Z, Pierret A, Portillo N, Roupsard O, Thammahacksa C, Stokes A (2015) Root functional parameters along a land-use gradient: evidence of a communitylevel economics spectrum. J Ecol 103:361-373. https://doi. org/10.1111/1365-2745.12351

Prieto I, Stokes A, Roumet C (2016) Root functional parameters predict fine root decomposability at the community level. J Ecol 104:725-733. https://doi.org/10.1111/1365-2745.12537

Qian B, Gameda S, De Jong R, Falloon P, Gornall J (2010) Comparing scenarios of Canadian daily climate extremes derived using a weather generator. Clim Res 41:131-149. https://doi.org/10.3354/cr00845

Rasse DP, Rumpel C, Dignac M-F (2005) Is soil carbon mostly root carbon? Mechanisms for a specific stabilisation. Plant Soil 269:341-356. https://doi.org/10.1007/s11104-0040907-y

Reid JB, Gray RAJ, Springett JA, Crush JR (2015) Root turnover in pasture species: chicory, lucerne, perennial ryegrass and white clover. Ann Appl Biol 167:327-342. https://doi. org/10.1111/aab.12228

Roumet C, Birouste M, Picon-Cochard C, Ghestem M, Osman N, Vrignon-Brenas S, Kf C, Stokes A (2016) Root structurefunction relationships in 74 species: evidence of a root economics spectrum related to carbon economy. New Phytol 210:815-826. https://doi.org/10.1111/nph.13828
Rumpel C, Kögel-Knabner I (2011) Deep soil organic matter-a key but poorly understood component of terrestrial $\mathrm{C}$ cycle. Plant Soil 338:143-158

Rytter RM, Rytter L (2012) Quantitative estimates of root densities at minirhizotrons differ from those in the bulk soil. Plant Soil 350:205-220. https://doi.org/10.1007/s11104-011-0896-6

SAS Institute Inc. (2006) Base SAS® 9.1.3 procedures guide, second edition, volumes 1, 2, 3, and 4. Cary, NC

Shapiro SS, Wilk MB (1965) An analysis of variance test for normality (complete samples). Biometrika 52:591-611

Smucker AJ, McBurney S, Srivastava A (1982) Quantitative separation of roots from compacted soil profiles by the Hydropneumatic elutriation system 1. Agron J 74:500-503

Soussana JF, Klumpp K, Ehrhardt F (2014) The role of grassland in mitigating climate change. The future of European grasslands 75: 75-90

Steen E (1989) Root biomass in timothy and red clover leys estimated by soil coring and mesh bags. J Agr Sci 113:241247

Tatti E, Goyer C, Chantigny M, Wertz S, Zebarth BJ, Burton DL, Filion M (2014) Influences of over winter conditions on denitrification and nitrous oxide-producing microorganism abundance and structure in an agricultural soil amended with different nitrogen sources. Agric Ecosyst Environ 183:4759. https://doi.org/10.1016/j.agee.2013.10.021

Weemstra M, Mommer L, Visser EJW, van Ruijven J, Kuyper TW, Mohren GMJ, Sterck FJ (2016) Towards a multidimensional root trait framework: a tree root review. New Phytol 211: 1159-1169. https://doi.org/10.1111/nph.14003

Wu Y, Deng Y, Zhang J, Wu J, Tang Y, Cao G, Zhang F, Cui X (2013) Root size and soil environments determine root lifespan: evidence from an alpine meadow on the Tibetan plateau. Ecol Res 28:493-501. https://doi.org/10.1007 /s11284-013-1038-9

Publisher's note Springer Nature remains neutral with regard to jurisdictional claims in published maps and institutional affiliations. 